ORIGINAL ARTICLE

\title{
Evaluation of texture of cheese by-products incorporated bread
}

\author{
Avaliação das características de textura de pão com \\ incorporação de subprodutos da produção do queijo
}

\section{Raquel de Pinho Ferreira Guiné ${ }^{*}$ [1]}

${ }^{1}$ Centro de Investigação CERNAS, Instituto Politécnico de Viseu, Departamento de Indústrias Alimentares, Escola Superior Agrária de Viseu, Ranhados, Viseu, Portugal.

*Corresponding Author: Raquel Guiné, Departamento de Indústrias Alimentares, Escola Superior Agrária de Viseu, Quinta da Alagoa, Estrada de Nelas, Ranhados, 3500-606, Viseu - Portugal, e-mail: raquelguine@esav.ipv.pt

Cite as: Guiné, R. P. F. (2020). Evaluation of texture of cheese by-products incorporated bread. Brazilian Journal of Food Technology, 23, e2019319. https://doi.org/10.1590/1981-6723.31919.

\begin{abstract}
This work aimed to develop new breads incorporating whey residue, "sorelho", obtained from ewe's milk after the production of Serra da Estrela Cheese. For this, we baked three types of bread: wheat bread (control sample), bread incorporating sorelho, and another version containing additional nutritional elements. The texture was evaluated with a texturometer, using compression and perforation tests. Results showed that sorelho can be successfully incorporated in bread. The best product was the bread with sorelho plus improved nutrition, which presented good textural characteristics during a period of 24 hours. This trend was observed for all properties evaluated: hardness, chewiness, resilience, cohesiveness, springiness (compression test) and external firmness, inner firmness, stickiness, adhesiveness (perforation test). Finally, factor analysis showed: FACTOR 1 - compression textural properties; FACTOR 2 - perforation firmness properties and FACTOR 3 perforation adhering properties, which in total explained approximately $81 \%$ of total variance.
\end{abstract}

Keywords: Compression test; Factorial analysis; Hardness; Perforation test; Residue valorization; Springiness.

\section{Resumo}

O objetivo deste trabalho foi desenvolver novos pães incorporando o sorelho, um resíduo do soro usado na produção de queijo Serra da Estrela a partir de leite de ovelha. Para isso, foram preparados três tipos de pão: pão de trigo (amostra controle), pão com sorelho e outra versão contendo elementos nutricionais adicionais. A textura foi avaliada com um texturômetro, por meio de testes de compressão e perfuração. Os resultados mostraram que o sorelho pode ser incorporado com sucesso no pão, e o melhor produto foi o pão com sorelho e formulação melhorada, que apresentou boas características de textura durante um período de 24 horas. Essa tendência foi observada em todas as propriedades avaliadas: dureza, mastigabilidade, resiliência, coesão, elasticidade (teste de compressão), firmeza externa, firmeza interna, pegajosidade e adesividade (teste de perfuração). Por fim, a análise fatorial permitiu extrair três fatores: FATOR 1 - propriedades texturais de compressão; FATOR 2 - propriedades da firmeza da perfuração; e FATOR 3 - propriedades aderentes da perfuração, que, no total, explicaram aproximadamente $81 \%$ da variação total.

Palavras-chave: Teste de compressão; Análise fatorial; Dureza; Teste de perfuração; Valorização de resíduos; Elasticidade. 


\section{Introduction}

In the past years, industrial food processing has led to a great increase in waste generation, and people show increased concern about the impact on the environment. Therefore, the concept of "zero waste" has been established in order to encourage people to search for strategies that reduce or eliminate waste production. The concept of circular economy envisages the reutilization and recycling of all types of waste, and in this way, the utilization of organic residues for the production of value added products, either for the food, pharmaceutical or cosmetic industries, allows the application of the circular economy concept in the organic waste management. In fact, food waste or agro-industrial waste corresponds to liquid or solid residues with a high organic load, bearing a strong impact on the environment and high treatment costs. Nevertheless, those wastes can be potentially reused within the food manufacturing chain. In many cases, they constitute a source of a wide variety of bioactive compounds, showing great potential for increasing food functionality (Alvarez et al., 2019; Barbosa-Ríos et al., 2018; de Oliveira et al., 2017).

The dairy industry is responsible for the generation of large amounts of liquid effluents, which are also typically characterized by a high organic load. In the manufacture of cheese, a serum is obtained from the pressing of the curd, that can be further used to produce whey cream cheese, which in turn, generates a byproduct called "sorelho". This by-product contains approximately $60 \%$ of the dry matter initially present in the whey, consisting essentially of lactose and mineral salts, posing a serious threat to the environment due to its high organic load. Additionally, sorelho also contains protein (up to $2 \%$ ) and minerals like calcium (up to $132 \mathrm{mg} / 100 \mathrm{~g}$ ), phosphorous (up to $133 \mathrm{mg} / 100 \mathrm{~g}$ ), sodium (up to $231 \mathrm{mg} / 100 \mathrm{~g}$ ), potassium (up to 594 $\mathrm{mg} / 100 \mathrm{~g}$ ) and magnesium (up to $33 \mathrm{mg} / 100 \mathrm{~g}$ ) (Akhlaghi et al., 2017; Azevedo, 2015; Pereira et al., 2002).

Bread is a universally consumed product, with a long tradition as a fundamental food product, basic in the diet of many populations around the world. Although bread consumption has gradually decreased over the most recent years, it still represents an important contribution to the diets in many cultures. Due to variable chemical composition of flours and utilized baking processes, breads form a food group with highly heterogeneous structures. Still, its versatility continues to evolve to meet the needs and expectations of the modern consumers, while at the same time adapting to innovations in terms of ingredients, equipment and technology. One of the trends is to use bread as a means to increase protein intake by adding protein rich products to the bread dough, or the fortification with dietary minerals from other food sources (Bar-El Dadon et al., 2017; Cauvain, 2015; Gao et al., 2018; Millar et al., 2019; Pentikäinen et al., 2014).

Bread texture is influenced by the mechanical properties of the crumb and the crust, which are in turn associated with the structural and physical characteristics of the bread matrix. A sequence of texture sensations is perceived by people while chewing bread due to the continuous transformation of its structure, mostly due to the particle size reduction and saliva impregnation processes. Bread quality changes remarkably with time, and therefore the losses of quality during storage must be minimized. Bread staling leads to the loss of resilience of the crumb, decrease of crispness of the crust, loss of volatile flavor compounds and soluble starch content (Gao et al., 2018; Gao et al., 2015; Jourdren et al., 2016; Peng et al., 2017; Pentikäinen et al., 2014).

This study aimed to develop new added-value bakery products incorporating sorelho, generated in relevant quantities in the dairies that produce cheese from ewe's milk in the central region of Portugal, the area of the Protected Designation of Origin Serra da Estrela cheese. This would allow the valorization of a resource with nutritional relevance while at the same time minimizing environmental impacts by finding alternative ways to use this residue. Furthermore, and because texture is pivotal in evaluation of bread quality, the textural properties of the breads developed were measured in different moments: after baking and up until a period of 24 hours. 


\section{Material and methods}

\subsection{Preparation of the samples}

\subsubsection{Control sample (C)}

A basic wheat bread recipe was used for control purposes. For this, $3 \mathrm{~kg}$ of refined wheat flour (grinding T65) were mixed with $2500 \mathrm{~mL}$ of warm water, previously heated at $30^{\circ} \mathrm{C}$. Then $60 \mathrm{~g}$ of fresh yeast were dissolved into $50 \mathrm{~mL}$ of warm water and added to the mixture. The salt was added $(60 \mathrm{~g})$ and the dough was kneaded for $15 \mathrm{~min}$ until obtaining the desired elasticity and homogeneity. The dough was left to stand in a chamber with controlled temperature for $20 \mathrm{~min}$ at $35^{\circ} \mathrm{C}$ to allow fermentation to develop. When the dough was ready, loaves of $100 \mathrm{~g}$ were molded into round shape breads that were left in the chamber at the same temperature for an additional period of 15 min. After that, the bread loaves were baked at $240{ }^{\circ} \mathrm{C}$ for $20 \mathrm{~min}$ in heated oven. At the beginning of the baking operation, after three minutes, two consecutive steam baths were performed, to avoid early formation of the crust.

This experimental procedure was also used to prepare the other types of bread, just with slight adaptations and change in terms of formulation as described below.

\subsubsection{Bread with cheese by-products (BCB)}

The most important changes in this formulation consisted in the replacement of water by the cheese byproduct: liquid sorelho. Due to the different nature of this liquid as compared to water, some changes were made resulting in the following formulation: $3 \mathrm{~kg}$ of the same refined wheat flour, $1600 \mathrm{~mL}$ of sorelho, $90 \mathrm{~g}$ of yeast and no added salt. This elimination of the salt results from the fact that sorelho is obtained from the manufacture of cheese and whey cheese, and therefore already contains some incorporated salt. This product can be considered as contributing to sustainability for using a residue that otherwise would be discarded, thus contributing for the practical implementation of circular economy.

\subsubsection{Bread with cheese by-products and improved nutrition (BCBIN)}

For this version of bread, further changes were introduced in the formulation to obtain a product with improved nutritional functions. This, besides the sustainability contribution, potentiates consumer preference, leading to buying and rebuying behavior, and contributing for a more environmentally friendly as well as nutritionally balanced option.

Globally, the main changes included partial replacement of refined flour by whole grain flour, addition of oat flakes and different types of seeds, thus contributing for additional supply of dietary fiber as well as other macro and micro nutrients. The quantities used were: $750 \mathrm{~g}$ of refined wheat flour, $2250 \mathrm{~g}$ of whole wheat flour, $1800 \mathrm{~mL}$ of sorelho, $90 \mathrm{~g}$ of yeast, $17 \mathrm{~g}$ of oat flakes, $194 \mathrm{~g}$ of pumpkin seeds, $12 \mathrm{~g}$ of chia seeds, $8 \mathrm{~g}$ of poppy seeds and $14 \mathrm{~g}$ of sesame seeds.

The analyses were performed 30 minutes and 6 hours after baking, the bread samples were left at room temperature (Figure 1). However, for the analyses performed 24 hours after baking, the samples were stored inside a closed common plastic bag until the next day.
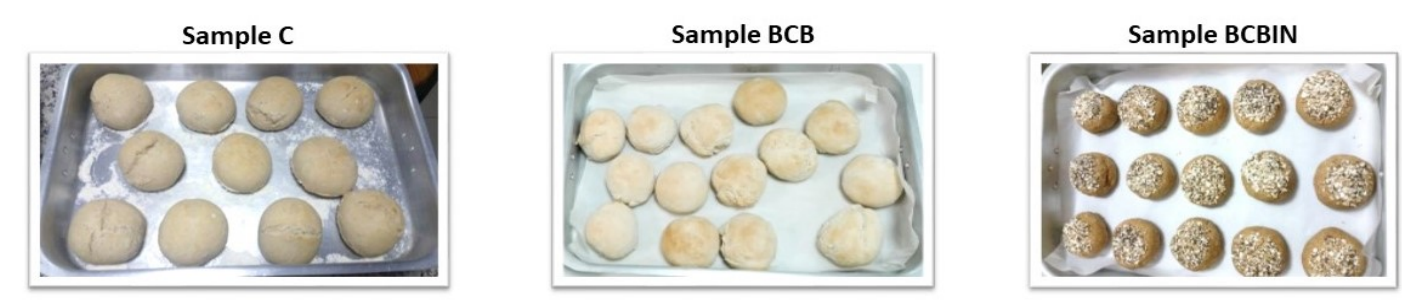

Figure 1. The three bread samples after baking. 


\subsection{Evaluation of texture}

The textural properties of all samples were assessed by instrumental texture analysis, using a texturometer TAXT2 from Stable Microsystems. We performed two types of complementing textural characteristics measurements: a compression test and a perforation test. Figure 2 shows the texturometer performing a perforation test.

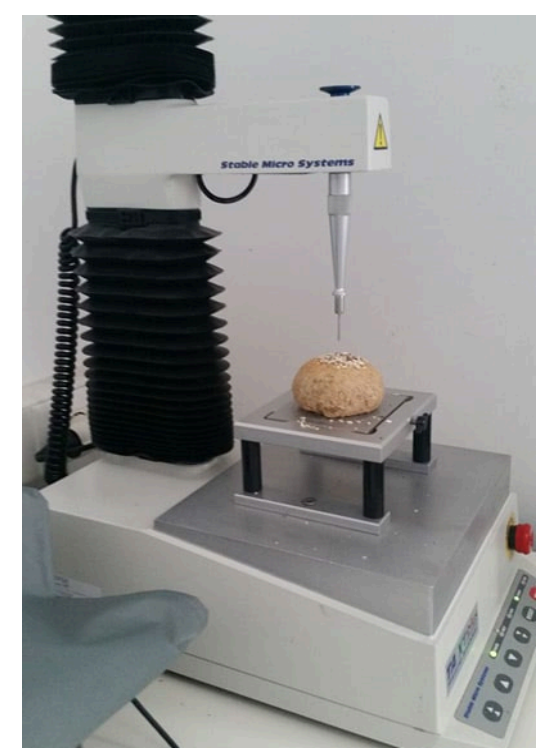

Figure 2. Texturometer performing a perforation test on a sample of BCBIN bread.

The samples were evaluated 30 minutes, 6 hours later and 24 hours after baking. The choice of intervals aimed at evaluating the texture closely after producing the bread, some hours later in the same day and in the following day. A longer evaluation period was discarded because this is a bread without preservatives, destined to be consumed in the day of baking or the next day at most.

\subsubsection{Compression test}

The texture profile analysis was obtained by compression test, consisting of two compression cycles separated by an interval of 5 seconds. The compression was done using a flat $75 \mathrm{~mm}$ diameter $(\mathrm{P} / 75)$ probe that compressed the sample against a flat surface. The load cell used was $30 \mathrm{~kg}$ force and the compression distance was $4 \mathrm{~mm}$, with pre-test, test, and post-test speeds equal to $1.0 \mathrm{~mm} / \mathrm{s}$.

The tests produced grafts in the form of Force (N) versus Time (s), consisting of two peaks. The results were processed using Exponent software TEE from Stable Micro Systems, and allowed calculating the textural properties: hardness, resilience, springiness, cohesiveness, and chewiness according to Equations 15 (Correia et al., 2017):

$$
\begin{aligned}
& \operatorname{Hardness}(\mathrm{N})=\mathrm{F}_{1} \\
& \text { Resilience }(\%)=\left(\mathrm{A}_{5} / \mathrm{A}_{4}\right) \times 100 \\
& \text { Springiness }(\%)=\left(\mathrm{T}_{2} / \mathrm{T}_{1}\right) \times 100 \\
& \text { Cohesiveness }(\%)=\left(\mathrm{A}_{2} / \mathrm{A}_{1}\right) \times 100 \\
& \text { Chewiness }(\mathrm{N})=\mathrm{F}_{1} \times\left(\mathrm{T}_{2} / \mathrm{T}_{1}\right) \times\left(\mathrm{A}_{2} / \mathrm{A}_{1}\right)
\end{aligned}
$$

Where $F_{1}$ is the force at the highest point in the first peak, $A_{1}$ and $A_{2}$ are the areas under the curve for the first and second peaks, $T_{1}$ and $T_{2}$ are the times elapsed between the beginning of a certain peak and the 
moment it reaches its highest point, and $\mathrm{A}_{4}$ and $\mathrm{A}_{5}$ are the areas in the first peak, with $\mathrm{A}_{4}$ being measured from the beginning until its highest point and $\mathrm{A}_{5}$ from the highest point until its end (Figure 3 ).

These compression tests were performed in eight loaves of each sample (C, BCB and BCBIN), and in each loaf two independent measurements were performed, one of the top side and another on the bottom side.

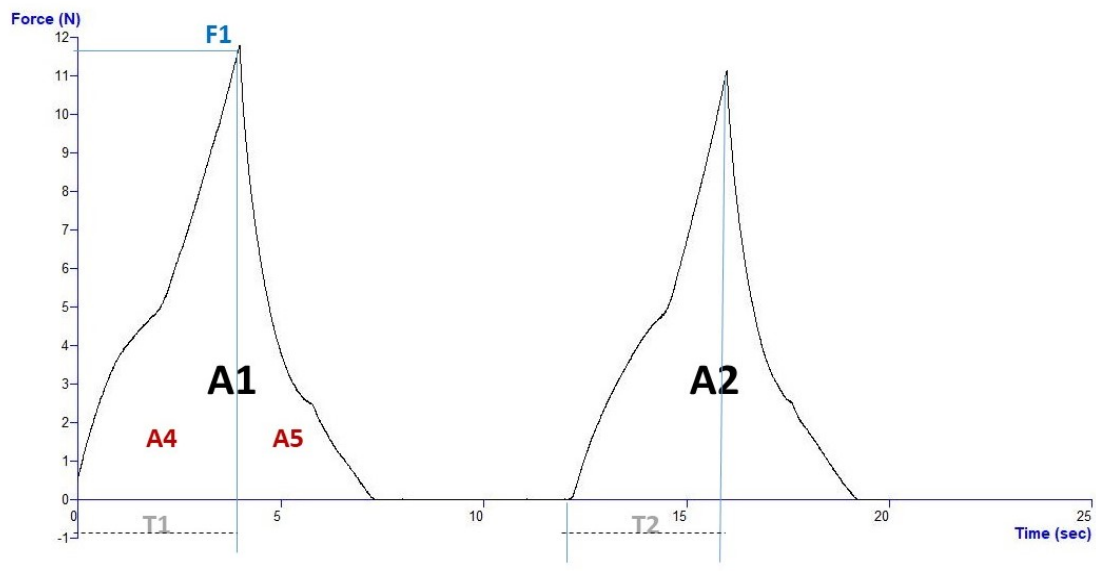

Figure 3. Example of a graph obtained for compression test.

\subsubsection{Perforation test}

The perforation test was performed with a drilling rig with $2 \mathrm{~mm}$ diameter $(\mathrm{P} / 2$ probe) and the perforation distance was $10 \mathrm{~mm}$. The pre-test speed was $2 \mathrm{~mm} / \mathrm{s}$, and the test and post-test speeds were $1 \mathrm{~mm} / \mathrm{s}$. The obtained graphs consist typically of a positive peak, corresponding to the strength required to penetrate the crust, followed by a lower baseline, corresponding to the strength required to penetrate the crumbs, and then a negative peak corresponding to the withdrawal of the probe form the bread sample. These graphs allowed calculating the following textural properties: crust firmness, inner firmness, adhesiveness, and stickiness. The crust firmness $(\mathrm{N})$ is the maximum force obtained in the positive peak, the inner firmness $(\mathrm{N})$ is calculated as an average force of the values in the baseline, adhesiveness (N.s) in the area of the negative peak, and stickiness (N) is the minimum force in the negative peak (Figure 4) (Guiné et al., 2019).

In this case, eight loaves of each type of bread were used, but the number of repetitions was different, since on each of the bread sides (top and bottom) six measurements were made.

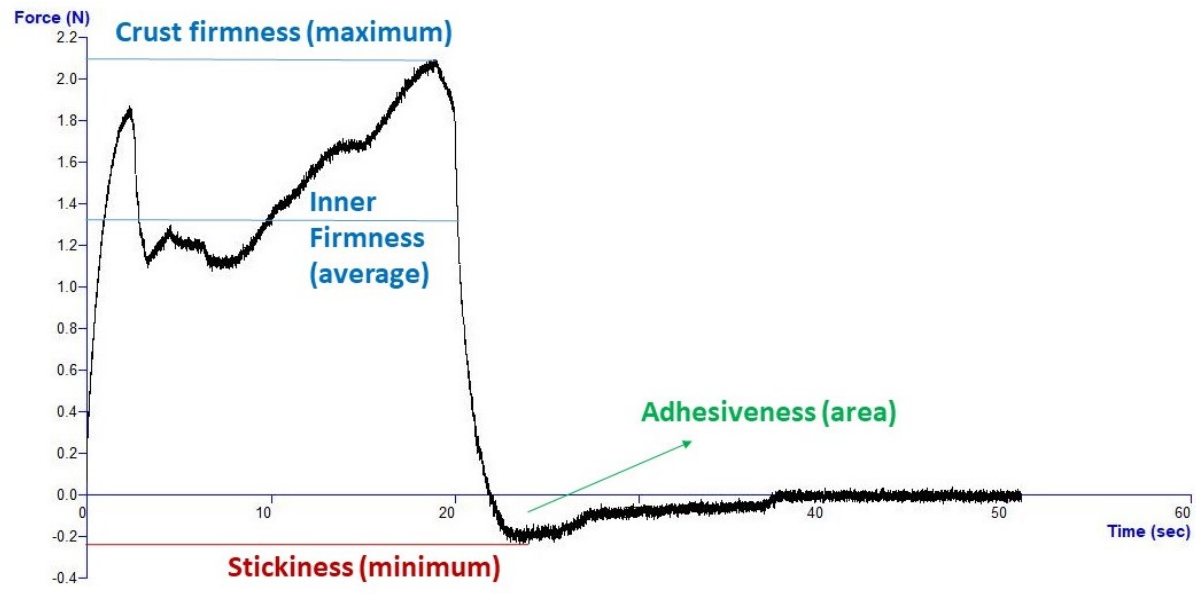

Figure 4. Example of a graph obtained for perforation test. 


\subsection{Statistical analysis}

The results obtained with the different repetitions were used to calculate the mean values and corresponding standard deviation. Differences were evaluated by statistical tests for comparison of means using analysis of variance (ANOVA), with the Post-hoc Tukey HSD (Honestly Significant Difference) test for identification of differences between samples (Maroco, 2012; Pestana \& Gageiro, 2014).

To complement the study, a factor analysis (FA) was performed. First the data were evaluated to confirm if it were proper for application of FA. For this the correlation matrix between the variables was analyzed to identify some correlations. Additionally, the Kaiser-Meyer-Olkin (KMO) measure of adequacy of the sample and the Bartlett's test were used to verify the inter-correlation between variables (Broen et al., 2015). After confirming that the data were suitable for application of FA, we applied the extraction by principal component analysis (PCA) considering Varimax rotation with Kaiser Normalization, i.e., the number of components was established for eigenvalues $\geq 1$. The communalities were calculated to indicate the percentage of variance explained by the factors extracted (Broen et al., 2015). Factor loadings with absolute values equal or higher than 0.4 were used (Rohm \& Swaminathan, 2004; Stevens, 2009).

For all statistical analyses was used the software SPSS version 25 (IBM, Inc.) and the level of significance considered was $5 \%(p<0.05)$.

\section{Results and discussion}

\subsection{Textural properties - compression test}

Table 1 shows the results obtained for the textural properties of the compression test: hardness, resilience, springiness, cohesiveness and chewiness. Hardness corresponds to the force required to compress the food between the teeth or between the palate and the tong. Chewiness is the energy necessary to disintegrate the food to make it suitable to swallow. Springiness is associated with the ability to recover shape after compression, corresponding to the rate of return to the initial point when the force that caused deformation is removed. Resilience is the energy used when applying a force to a material without occurring rupture, with or without any residual strain, and corresponds to an instant springiness. Cohesiveness represents the internal forces inside the food that keep the sample cohesive, preventing it from disintegrating (Cruz et al., 2015; Guiné et al., 2014; Guiné et al., 2015).

The results in Table 1 indicate that hardness was practically the same after baking for the three samples but varied considerably over the evaluation period of 24 hours considered. At time equal to 30 minutes, hardness was $11.80,14.85$ and $9.51 \mathrm{~N}$ for samples $\mathrm{C}, \mathrm{BCB}$ and BCBIN, respectively. We observed a decrease of $25 \%$ for the control sample and $16 \%$ for the BCB sample, while sample BCBIN became harder, $55 \%$. This increase in hardness of bread as time passes is expected, as reported by Barbosa-Ríos et al. (2018). On the other hand, according to Ozturk \& Mert (2018) the solubilized proteins, which are present in the whey residue, can produce a more homogenous structure, giving place to softer products, like it happened with sample BCB.

Also, springiness was quite variable, being lower for the BCB sample right after baking (90.85\%) as compared with the other two samples $(93.56 \%$ and $95.77 \%$ for samples $\mathrm{C}$ and BCBIN, respectively). Springiness remained practically the same after 24 hours, just increasing slightly for samples C and BCB, meaning that the elasticity of these three types of bread was not altered during this period of time. Contrarily, Ozturk \& Mert (2018) reported a decrease in springiness along time for gluten-free corn breads, corresponding to a loss in elasticity.

According to Agama-Acevedo et al. (2019) the textural properties hardness and elasticity tend to increase with time for white bread, as a consequence of incomplete starch gelatinization and retrogradation. Furthermore, for the crust of white bread they observed a structural arrangement of the starch components, 
feasibly due to the low water content resulting from evaporation during baking as well as along storage (Agama-Acevedo et al., 2019).

Regarding chewiness, the value was considerably higher for sample $\mathrm{BCB}$ in the first evaluation moment $(14.23 \mathrm{~N})$ as compared with the other samples (9.22 and $7.56 \mathrm{~N}$, respectively for $\mathrm{C}$ and BCBIN). The values of this textural property decreased along time for the control (8\%), while increasing for sample $\mathrm{BCB}$ and BCBIN (5\% and 60\%, respectively). The increase of chewiness for sample BCBIN is directly related with the increase in hardness, since these two properties are directly related according to Equation 5.

The properties resilience and cohesiveness were very similar for the three types of bread evaluated, with resilience slightly increasing during the 24 hours' period considered (with variations between $7 \%$ and $12 \%$, respectively for samples $\mathrm{BCBIN}$ and $\mathrm{C})$ and cohesiveness increasing also but in an even lower extent (6\%, $9 \%$ and $1 \%$ for samples $\mathrm{C}, \mathrm{BCB}$ and $\mathrm{BCBIN}$, respectively).

Figure 5 shows the variation along the evaluation period of 24 hours of the compression textural properties for the improved bread sample, BCBIN, for being the one with highest commercial potential. The graphs show that the changes take place mostly in the first 6 hours, i.e., a few hours after baking, and that from 6 to 24 hours all properties remain practically unchanged. This is relevant because it highlights the capability of this bread for conservation for a whole day, providing that it is kept under a closed plastic bag. This is a type of bread aimed at consuming fresh, after some hours of baking, due to the total absence of preservatives. Hence, its texture seems to remain relatively unaltered from the baking day to the next.

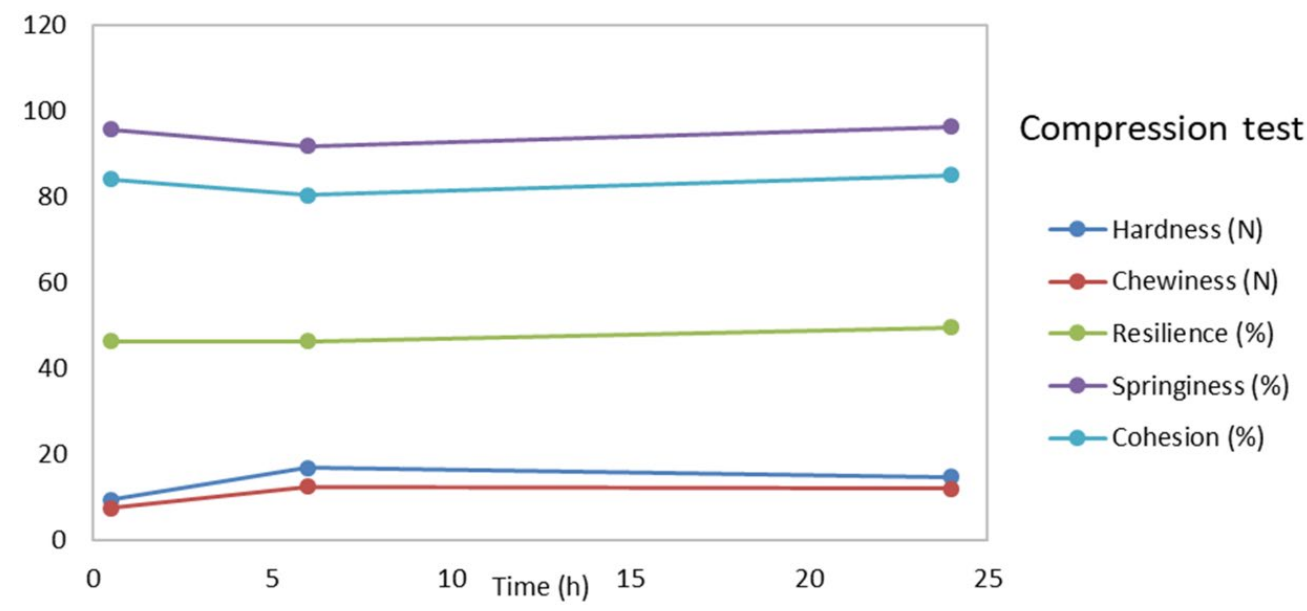

Figure 5. Variation of the compression textural properties along time for sample BCBIN.

Table 1. Textural properties evaluated by the compression test.

\begin{tabular}{|c|c|c|c|c|c|c|}
\hline Sample $^{1}$ & Time (h) & $\operatorname{Hardness}^{2}(\mathrm{~N})$ & Resilience $^{2}(\%)$ & Cohesion $^{2}(\%)$ & Springiness $^{2}(\%)$ & Chewiness $^{2}(\mathrm{~N})$ \\
\hline \multirow{3}{*}{$\mathrm{C}$} & 0.5 & $11.80 \pm 3.11^{\mathrm{abc}}$ & $48.57 \pm 4.31^{\mathrm{ab}}$ & $83.06 \pm 5.50^{\mathrm{abc}}$ & $93.56 \pm 1.75^{\mathrm{abc}}$ & $9.22 \pm 2.60^{\mathrm{ab}}$ \\
\hline & 6 & $14.85 \pm 5.15^{\mathrm{ab}}$ & $45.78 \pm 4.20^{\mathrm{a}}$ & $81.97 \pm 7.11^{\mathrm{abc}}$ & $93.88 \pm 3.48^{\mathrm{abc}}$ & $11.19 \pm 2.93^{\mathrm{abc}}$ \\
\hline & 24 & $8.90 \pm 2.79^{\mathrm{cd}}$ & $54.16 \pm 7.66^{b}$ & $88.27 \pm 4.86^{\mathrm{d}}$ & $98.67 \pm 0.26^{\mathrm{d}}$ & $8.48 \pm 3.18^{\mathrm{ab}}$ \\
\hline \multirow{3}{*}{$\mathrm{BCB}$} & 0.5 & $19.23 \pm 3.15^{\mathrm{de}}$ & $46.58 \pm 6.17^{\mathrm{a}}$ & $81.66 \pm 8.98^{\mathrm{abc}}$ & $90.85 \pm 3.02^{\mathrm{a}}$ & $14.23 \pm 1.20^{\mathrm{cd}}$ \\
\hline & 6 & $22.34 \pm 3.12^{\mathrm{e}}$ & $43.68 \pm 6.43^{\mathrm{a}}$ & $77.75 \pm 8.85^{\mathrm{ab}}$ & $92.48 \pm 2.54^{\mathrm{abc}}$ & $16.05 \pm 2.04^{\mathrm{d}}$ \\
\hline & 24 & $16.07 \pm 5.05^{\mathrm{cd}}$ & $50.12 \pm 4.73^{\mathrm{ab}}$ & $88.93 \pm 5.62^{c}$ & $97.07 \pm 1.75^{\mathrm{cd}}$ & $14.89 \pm 4.27^{\mathrm{cd}}$ \\
\hline \multirow{3}{*}{ BCBIN } & 0.5 & $9.51 \pm 2.93^{\mathrm{ab}}$ & $46.45 \pm 2.75^{\mathrm{a}}$ & $84.12 \pm 4.10^{\mathrm{abc}}$ & $95.77 \pm 2.95^{\mathrm{bcd}}$ & $7.56 \pm 1.85^{\mathrm{a}}$ \\
\hline & 6 & $16.89 \pm 4.72^{\mathrm{cd}}$ & $46.49 \pm 4.92^{\mathrm{a}}$ & $80.50 \pm 5.69^{\mathrm{bc}}$ & $91.90 \pm 3.48^{\mathrm{ab}}$ & $12.56 \pm 3.84^{\mathrm{ab}}$ \\
\hline & 24 & $14.77 \pm 4.02^{\mathrm{bcd}}$ & $49.71 \pm 3.15^{\mathrm{ab}}$ & $85.06 \pm 2.34^{\mathrm{abc}}$ & $96.39 \pm 2.50^{\text {bcd }}$ & $12.07 \pm 3.16^{\text {bcd }}$ \\
\hline
\end{tabular}

${ }^{1} \mathrm{C}=$ Control sample (wheat bread); $\mathrm{BCB}=$ Bread with Cheese by-products; BCBIN = BCB with cheese by-products and improved nutrition ${ }^{2}$ For each column, values with the same superscript letter are not significantly different (ANOVA with Tukey post-hoc test, $\mathrm{p}>0.005$ ). 
Table 2 presents the values obtained for the textural properties measured with the perforation test: crust firmness. inner firmness, adhesiveness and stickiness. The external and internal firmness measure the force corresponding to the resistance of the crust and the inner crumbs, respectively. Adhesiveness represents the negative area after the probe was removed from the sample and corresponds to the force required to remove the material that adheres to a specific surface (e.g., lips, palate, teeth). Stickiness is also related to adhesiveness and corresponds to the minimum force (negative value) registered by the probe right before starting to retract from the sample.

The crust and inner firmness were highest for sample $\mathrm{BCB}$ along the whole evaluation period, being lowest for the control sample (Table 2). Sample BCBIN showed intermediate values of firmness, increasing slightly form the first to the last evaluation moments ( $7 \%$ and $20 \%$, respectively for crust and inner firmness). The variation in these properties for the control sample along the same period was $-29 \%$ and $-5 \%$, respectively for crust and inner firmness, meaning that the control bread suffered a pronounced loss of firmness, particularly in the case of the crust. It has been reported that bread crust loses its crispness just a few hours after baking owing to water uptake from the soft and moist crumb, and hence, the crispy texture of the crust is directly related to the water uptake kinetics (Meinders \& van Vliet, 2011).

The water distribution in bread is irregular, with some parts getting swallowed with water while in the remaining parts the water is as free water. The swelling is caused by the starch granules of the gluten network, as well as owing to the repelling action of lipids, through hydrogen bonds, hydrophobic interaction, Van der Waals force, and other interactions (Curti et al., 2011; Ding et al., 2019). This uneven water distribution, as well as different rates of dehydration, is also a cause of differentiation between the textural properties of the crust and the inner crumbs in bread.

While stickiness and adhesiveness increased drastically along time for samples $\mathrm{C}$ and $\mathrm{BCB}$, they remained practically constant for sample BCBIN, with variations of only $4 \%$ and $8 \%$, respectively.

Similarly to what was observed for the variation of the compression textural properties, also the perforation properties of the BCBIN type of bread remain practically unchanged after 24 hours (Figure 6).

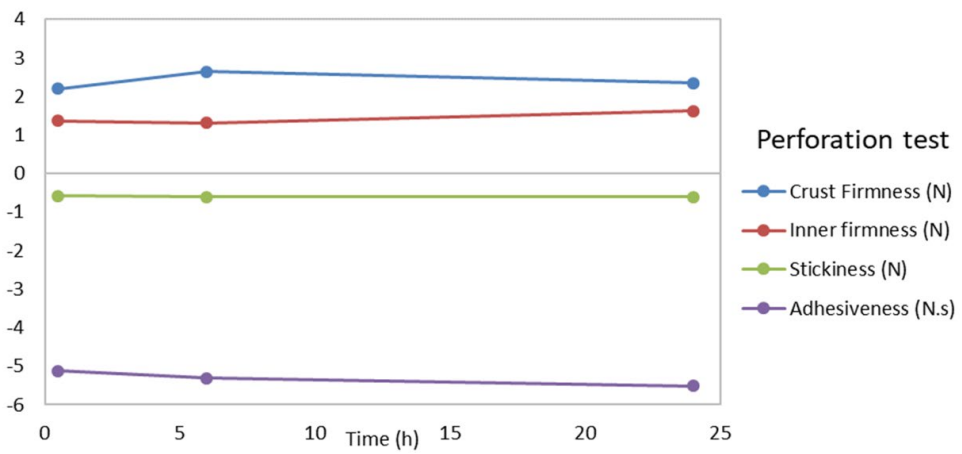

Figure 6. Variation of the perforation textural properties along time for sample BCBIN.

Table 2. Textural properties evaluated by the perforation test.

\begin{tabular}{|c|c|c|c|c|c|}
\hline Sample $^{1}$ & Time (h) & Crust firmness $^{2}(\mathrm{~N})$ & Inner firmness $^{2}(\mathrm{~N})$ & Stickiness $^{2}$ (N) & Adhesiveness $^{2}$ (N.s) \\
\hline \multirow{3}{*}{$\mathrm{C}$} & 0.5 & $1.56 \pm 0.54^{\mathrm{ab}}$ & $0.76 \pm 0.15^{\mathrm{a}}$ & $-0.44 \pm 0.21^{\mathrm{bc}}$ & $-4.01 \pm 2.25^{\mathrm{ab}}$ \\
\hline & 6 & $1.85 \pm 0.64^{\mathrm{abc}}$ & $0.82 \pm 0.17^{\mathrm{a}}$ & $-0.48 \pm 0.18^{\mathrm{abc}}$ & $-4.34 \pm 2.09^{\mathrm{ab}}$ \\
\hline & 24 & $1.10 \pm 0.21^{\mathrm{a}}$ & $0.72 \pm 0.22^{\mathrm{a}}$ & $-0.38 \pm 0.07^{c}$ & $-3.29 \pm 0.80^{b}$ \\
\hline \multirow{3}{*}{$\mathrm{BCB}$} & 0.5 & $4.62 \pm 1.99^{f}$ & $1.76 \pm 0.56^{\mathrm{c}}$ & $-0.66 \pm 0.43^{a}$ & $-5.82 \pm 3.49^{a}$ \\
\hline & 6 & $4.51 \pm 1.51^{\mathrm{f}}$ & $1.75 \pm 0.38^{c}$ & $-0.60 \pm 0.25^{\mathrm{ab}}$ & $-5.60 \pm 3.33^{a}$ \\
\hline & 24 & $3.00 \pm 1.00^{\mathrm{e}}$ & $1.74 \pm 0.71^{\mathrm{c}}$ & $-0.51 \pm 0.14^{\mathrm{abc}}$ & $-4.14 \pm 1.88^{a b}$ \\
\hline \multirow{3}{*}{ BCBIN } & 0.5 & $2.20 \pm 0.56^{\mathrm{bcd}}$ & $1.36 \pm 0.36^{\mathrm{b}}$ & $-0.58 \pm 0.19^{\mathrm{ab}}$ & $-5.12 \pm 2.14^{\mathrm{ab}}$ \\
\hline & 6 & $2.64 \pm 0.88^{\mathrm{de}}$ & $1.32 \pm 0.31^{\mathrm{b}}$ & $-0.61 \pm 0.27^{\mathrm{ab}}$ & $-5.31 \pm 2.52^{\mathrm{a}}$ \\
\hline & 24 & $2.35 \pm 0.43^{\text {cde }}$ & $1.63 \pm 0.48^{\mathrm{bc}}$ & $-0.60 \pm 0.28^{\mathrm{ab}}$ & $-5.51 \pm 2.43^{\mathrm{a}}$ \\
\hline
\end{tabular}

${ }^{1} \mathrm{C}=$ Control sample (wheat bread); $\mathrm{BCB}=$ Bread with Cheese by-products; $\mathrm{BCBIN}=\mathrm{BCB}$ with cheese by-products and improved nutrition.

${ }^{2}$ For each column, values with the same superscript letter are not significantly different (ANOVA with Tukey post-hoc test, $\mathrm{p}>0.005$ ). 


\subsection{Factor analysis}

Table 3 shows the correlation matrix between the variables. The values reveal some meaningful correlations between the variables, with 11 values higher than 0.4 , and the highest value very close to 1 (0.968). These correlations confirm some important associations between the variables, thus permitting to apply FA to the data. Furthermore, the value of KMO was acceptable (0.533) according to the classification of Kaiser and Rice (Kaiser \& Rice, 1974), and the Bartlett's test of sphericity indicated adequacy for applying FA, since the $p$-value was significant $\left(\chi^{2}=197.65 ; p<0.0005\right)$, thus leading to the rejection of the null hypothesis that the correlation matrix was equal to the identity matrix.

Table 3. Correlation matrix.

\begin{tabular}{|c|c|c|c|c|c|c|c|c|c|}
\hline $\begin{array}{c}\text { Textural } \\
\text { Properties } 1\end{array}$ & C-HA & C-RE & C-CO & C-SP & C-CH & P-CF & P-IF & P-ST & P-AD \\
\hline C-HA & 1.000 & & & & & & & & \\
\hline C-RE & -0.501 & 1.000 & & & & & & & \\
\hline C-CO & -0.698 & 0.867 & 1.000 & & & & & & \\
\hline C-SP & -0.490 & 0.506 & 0.618 & 1.000 & & & & & \\
\hline C-CH & 0.968 & -0.309 & -0.530 & -0.341 & 1.000 & & & & \\
\hline P-CF & 0.519 & -0.313 & -0.305 & -0.196 & 0.455 & 1.000 & & & \\
\hline P-IF & 0.258 & -0.247 & -0.081 & -0.062 & 0.186 & 0.829 & 1.000 & & \\
\hline P-ST & 0.223 & -0.092 & -0.307 & -0.068 & 0.223 & -0.042 & -0.190 & 1.000 & \\
\hline P-AD & -0.026 & 0.070 & -0.067 & 0.140 & -0.013 & -0.025 & -0.050 & 0.847 & 1.000 \\
\hline
\end{tabular}

${ }^{1} \mathrm{C}$ - = Compression test $/ \mathrm{P}-=$ Perforation test; HA = Hardness; $\mathrm{RE}=$ Resilience; $\mathrm{CO}=$ Cohesiveness; $\mathrm{SP}=\mathrm{Springiness} ; \mathrm{CH}=\mathrm{Chewiness}$; $\mathrm{CF}=$ Crust Firmness; $\mathrm{IF}=$ Inner Firmness; $\mathrm{ST}=$ Stickiness $; \mathrm{AD}=$ Adhesiveness.

By analyzing the values of MSA (Measure of Sampling Adequacy) obtained from the anti-image matrix, we found that practically all of them were higher that 0.5 (Table 4), denoting that, in general, the variables were proper for inclusion in the analysis, just with exception of chewiness from the compression test, inner firmness form the perforation test and adhesiveness from the perforation test, which values were lower than $0.5(0.469,0.458$ and 0.452 , respectively). Nevertheless, and because these values were still close to 0.5 , all variables were included in the following analysis.

FA with extraction by PCA (Principal Component Analysis) produced three components, based on the Keiser criterion to consider eigenvalues greater than 1 . This solution explained $80.61 \%$ of total variance, distributed by the three factors as follows: $\mathrm{F} 1$ (Variance explained, $\mathrm{VE}=36.82 \%$, eigenvalue $=3.79) ; \mathrm{F} 2(\mathrm{VE}=22.56 \%$, eigenvalue $=$ $1.99)$ and $\mathrm{F} 3(\mathrm{VE}=21.23 \%$, eigenvalue $=1.47)$. The analysis of the communalities revealed that the variable stickiness from the perforation test had the largest fraction of variance explained by the solution, corresponding to $94.8 \%$ (Table 4). Furthermore, there were no variables with communalities lower than 0.4 .

Table 4. Values of MSA (measure of sample adequacy) obtained from the anti-image matrix and communalities obtained by PCA (Principal Component Analysis).

\begin{tabular}{|c|c|c|}
\hline Textural Properties ${ }^{1}$ & MSA $^{2}$ & Communalities \\
\hline C-HA & 0.535 & 0.829 \\
\hline C-RE & 0.699 & 0.647 \\
\hline $\mathrm{C}-\mathrm{CO}$ & 0.567 & 0.882 \\
\hline C-SP & 0.555 & 0.611 \\
\hline $\mathrm{C}-\mathrm{CH}$ & 0.469 & 0.631 \\
\hline P-CF & 0.659 & 0.916 \\
\hline P-IF & 0.458 & 0.869 \\
\hline P-ST & 0.538 & 0.948 \\
\hline P-AD & 0.452 & 0.921 \\
\hline
\end{tabular}

${ }^{1} \mathrm{C}-=$ Compression test $/$ P- $=$ Perforation test; $\mathrm{HA}=$ Hardness; $\mathrm{RE}=$ Resilience; $\mathrm{CO}=$ Cohesiveness; $\mathrm{SP}=$ Springiness; $\mathrm{CH}=\mathrm{Chewiness}$; $\mathrm{CF}=$ Crust Firmness; $\mathrm{IF}=$ Inner Firmness; $\mathrm{ST}=$ Stickiness; $\mathrm{AD}=$ Adhesiveness. ${ }^{2} \mathrm{MSA}=$ Measure of Sample Adequacy. 
The PCA solution was then improved using Varimax rotation, which converged in five iterations and extracted three factors, as previously mentioned, grouping the variables as shown in Table 5. For this, variables with loadings under 0.4 were excluded. The obtained solution clearly separates the textural properties according to the test performed and the nature of the measurements. This is in accordance with the nature of the tests, since the compression test measures the effect of exerting a force on the external surface of the sample while perforation test involves the penetration inside the sample. In this way, the first deals mostly with the crust, while the second deals with the crust and more deeply with the crumbs.

For Factor 1 (Compression Textural Properties), the loadings of the variables were all quite high and particularly for variable cohesiveness (0.927). Regarding Factor 2 (Perforation Firmness Properties), the loadings of both variables were very high ( 0.921 and 0.925 , respectively for crust and inner firmness), which indicates that both variables contributed importantly for the definition of this factor. Finally, Factor 3 (Perforation Adhering Properties), which included the variables related to the adhering nature of the crumbs, also had very significant contributions of both variables ( 0.948 and 0.953 for stickiness and adhesiveness, respectively).

Table 5. Component matrix obtained by FA (factor analysis) with Varimax rotation.

\begin{tabular}{cccc}
\hline Textural Properties $^{1}$ & $\begin{array}{c}\text { FACTOR 1: Compression } \\
\text { Textural Properties }\end{array}$ & $\begin{array}{c}\text { FACTOR 2: Perforation } \\
\text { Firmness Properties }\end{array}$ & $\begin{array}{c}\text { FACTOR 3: Perforation } \\
\text { Adhering Properties }\end{array}$ \\
\hline C-HA & -0.810 & $(*)$ & $(*)$ \\
\hline C-RE & 0.795 & $(*)$ & $(*)$ \\
\hline C-CO & 0.927 & $(*)$ & $(*)$ \\
\hline C-SP & 0.768 & $(*)$ & $(*)$ \\
\hline C-CH & -0.675 & 0.921 & $(*)$ \\
\hline P-CF & $(*)$ & 0.925 & $(*)$ \\
\hline P-IF & $(*)$ & $(*)$ & 0.948 \\
\hline P-ST & $(*)$ & $(*)$ & 0.953
\end{tabular}

${ }^{1} \mathrm{C}$ - = Compression test $/$ P- = Perforation test; $\mathrm{HA}=$ Hardness; $\mathrm{RE}=$ Resilience; $\mathrm{CO}=$ Cohesiveness; $\mathrm{SP}=$ Springiness; $\mathrm{CH}=\mathrm{Chewiness}$; $\mathrm{CF}=$ Crust Firmness; IF = Inner Firmness; ST = Stickiness; AD = Adhesiveness. $(*)$ Loading factors under 0.4 were excluded.

\section{Conclusions}

The compression test results indicated that the incorporation of cheese by-products (sorelho) allowed producing breads that, after baking, showed lower hardness and chewiness but higher springiness, while having similar resilience and cohesiveness as compared with the control. On the other hand, the results from the perforation test showed that the developed breads had higher crust and inner firmness, but lower stickiness and adhesiveness. Furthermore, regarding the variation of the textural properties along time, the sample with sorelho and improved recipe (BCBIN) increased hardness and chewiness but maintained springiness, resilience, and cohesiveness practically constant over the 24 hours' period of evaluation. The same sample also showed constant textural attributes as measured by the perforation test.

Factor analysis allowed extracting three factors: FACTOR 1, accounting for the compression textural properties; FACTOR 2, corresponding to the perforation firmness properties and FACTOR 3, including the perforation adhering properties. In global these factors explain slightly over $80 \%$ of total variance in the textural properties. Finally, the loading factors of the variables for the factors are high, most especially for factors 2 and 3, revealing the impact of these properties for the definition of the corresponding factors.

Thus, the work developed concludes that sorelho, a whey cheese by-product, can be applied to produce bread with acceptable textural characteristics. 


\section{Acknowledgements}

This study was supported by Instituto Politécnico de Viseu/CI\&DETS through project PROJ/CI\&DETS/CGD/0007 and FCT - Fundação para a Ciência e Tecnologia, I.P., under the project UID/Multi/04016/2016.

\section{References}

Agama-Acevedo, E., Pacheco-Vargas, G., Gutierrez-Meraz, F., Tovar, J., \& Bello-Perez, L. A. (2019). Dietary fiber content, texture, and in vitro starch digestibility of different white bread crusts. Journal of Cereal Science, 89, 102824. http://dx.doi.org/10.1016/j.jcs.2019.102824

Akhlaghi, M., Boni, M. R., De Gioannis, G., Muntoni, A., Polettini, A., Pomi, R., Rossi, A., \& Spiga, D. (2017). A parametric response surface study of fermentative hydrogen production from cheese whey. Bioresource Technology, 244(Pt 1), 473-483. PMid:28803097. http://dx.doi.org/10.1016/j.biortech.2017.07.158

Alvarez, M. V., Cabred, S., Ramirez, C. L., \& Fanovich, M. A. (2019). Valorization of an agroindustrial soybean residue by supercritical fluid extraction of phytochemical compounds. The Journal of Supercritical Fluids, 143, 90-96. http://dx.doi.org/10.1016/j.supflu.2018.07.012

Azevedo, B. M. B. (2015). Ultrafiltração de concentrados de soro de leite de mistura para fabrico de requeijão. Lisboa, Portugal: Instituto Superior Técnico.

Barbosa-Ríos, J. A., Castillón-Jardón, J., Guadarrama-Lezama, A. Y., Alvarez-Ramirez, J., Meraz, M., \& Carrillo-Navas, H. (2018). Effect of new generation enzymes addition on the physical, viscoelastic and textural properties of traditional Mexican sweet bread. Journal of Cereal Science, 79, 160-167. http://dx.doi.org/10.1016/j.jcs.2017.10.012

Bar-El Dadon, S., Abbo, S., \& Reifen, R. (2017). Leveraging traditional crops for better nutrition and health: the case of chickpea. Trends in Food Science \& Technology, 64, 39-47. http://dx.doi.org/10.1016/j.tifs.2017.04.002

Broen, M. P. G., Moonen, A. J. H., Kuijf, M. L., Dujardin, K., Marsh, L., Richard, I. H., Starkstein, S. E., Martinez-Martin, P., \& Leentjens, A. F. G. (2015). Factor analysis of the Hamilton Depression Rating Scale in Parkinson's disease. Parkinsonism \& Related Disorders, 21(2), 142-146. PMid:25523963. http://dx.doi.org/10.1016/j.parkreldis.2014.11.016

Cauvain, S. (2015). Technology of Breadmaking (3rd ed.). Retrieved in 2020, July 21, from https://www.springer.com/gp/book/9783319146867

Correia, P., Guiné, R., Correia, A. C., Gonçalves, F., Brito, M., \& Ribeiro, J. (2017). Physical, chemical and sensory properties of kiwi as influenced by drying conditions. Agricultural Engineering International, 19(3), 203-212.

Cruz, A. C., Guiné, R. P. F., \& Gonçalves, J. C. (2015). Drying kinetics and product quality for convective drying of apples (cvs. Golden Delicious and Granny Smith). International Journal of Fruit Science, 15(1), 54-78. http://dx.doi.org/10.1080/15538362.2014.931166

Curti, E., Bubici, S., Carini, E., Baroni, S., \& Vittadini, E. (2011). Water molecular dynamics during bread staling by Nuclear Magnetic Resonance. Lebensmittel-Wissenschaft + Technologie, 44(4), 854-859. http://dx.doi.org/10.1016/j.Iwt.2010.11.021 de Oliveira, L. M., da Silva Lucas, A. J., Cadaval, C. L., \& Mellado, M. S. (2017). Bread enriched with flour from cinereous cockroach (Nauphoeta cinerea). Innovative Food Science \& Emerging Technologies, 44, 30-35. http://dx.doi.org/10.1016/j.ifset.2017.08.015

Ding, S., Peng, B., Li, Y., \& Yang, J. (2019). Evaluation of specific volume, texture, thermal features, water mobility, and inhibitory effect of staling in wheat bread affected by maltitol. Food Chemistry, 283, 123-130. PMid:30722851. http://dx.doi.org/10.1016/j.foodchem.2019.01.045

Gao, J., Tay, S. L., Koh, A. H.-S., \& Zhou, W. (2018). Dough and bread making from high- and low-protein flours by vacuum mixing: Part 3. Oral processing of bread. Journal of Cereal Science, 79, 408-417. http://dx.doi.org/10.1016/j.jcs.2017.12.002

Gao, J., Wong, J. X., Lim, J. C.-S., Henry, J., \& Zhou, W. (2015). Influence of bread structure on human oral processing. Journal of Food Engineering, 167, 147-155. http://dx.doi.org/10.1016/j.jfoodeng.2015.07.022

Guiné, R. P. F., Henriques, F., \& Barroca, M. J. (2014). Influence of drying treatments on the physical and chemical properties of cucumber. Journal of Food Measurement and Characterization, 8(3), 195-206. http://dx.doi.org/10.1007/s11694-014-9180-9

Guiné, R. P. F., Almeida, I. C., Correia, A. C., \& Gonçalves, F. J. (2015). Evaluation of the physical, chemical and sensory properties of raisins produced from grapes of the cultivar Crimson. Journal of Food Measurement and Characterization, $9(3)$, 337-346. http://dx.doi.org/10.1007/s11694-015-9241-8

Guiné, R. P. F., Fontes, L., \& Lima, M. J. (2019). Evaluation of texture in Serra da Estrela cheese manufactured in different dairies. Open Agriculture, 4(1), 475-486. http://dx.doi.org/10.1515/opag-2019-0048

Jourdren, S., Panouillé, M., Saint-Eve, A., Déléris, I., Forest, D., Lejeune, P., \& Souchon, I. (2016). Breakdown pathways during oral processing of different breads: impact of crumb and crust structures. Food \& Function, 7(3), 1446-1457. PMid:26857555. http://dx.doi.org/10.1039/C5FO01286D

Kaiser, H. F., \& Rice, J. (1974). Little Jiffy, Mark Iv. Educational and Psychological Measurement, 34(1), 111-117. http://dx.doi.org/10.1177/001316447403400115

Maroco, J. (2012). Análise Estatística com o SPSS Statistics (5. ed.). Lisboa: ReportNumber. 
Meinders, M. B. J., \& van Vliet, T. (2011). Oscillatory water sorption dynamics of bread crust. Food Research International, 44(9), 2814-2821. http://dx.doi.org/10.1016/j.foodres.2011.06.027

Millar, K. A., Barry-Ryan, C., Burke, R., McCarthy, S., \& Gallagher, E. (2019). Dough properties and baking characteristics of white bread, as affected by addition of raw, germinated and toasted pea flour. Innovative Food Science \& Emerging Technologies, 56, 102189. http://dx.doi.org/10.1016/j.ifset.2019.102189

Ozturk, O. K., \& Mert, B. (2018). The effects of microfluidization on rheological and textural properties of gluten-free corn breads. Food Research International, 105, 782-792. PMid:29433274. http://dx.doi.org/10.1016/j.foodres.2017.12.008

Peng, B., Li, Y., Ding, S., \& Yang, J. (2017). Characterization of textural, rheological, thermal, microstructural, and water mobility in wheat flour dough and bread affected by trehalose. Food Chemistry, 233, 369-377. PMid:28530586. http://dx.doi.org/10.1016/j.foodchem.2017.04.108

Pentikäinen, S., Sozer, N., Närväinen, J., Ylätalo, S., Teppola, P., Jurvelin, J., Holopainen-Mantila, U., Törrönen, R., Aura, A.M., \& Poutanen, K. (2014). Effects of wheat and rye bread structure on mastication process and bolus properties. Food Research International, 66, 356-364. http://dx.doi.org/10.1016/j.foodres.2014.09.034

Pereira, C. D., Diaz, O., \& Cobos, A. (2002). Valorization of by-products from ovine cheese manufacture: clarification by thermocalcic precipitation/microfiltration before ultrafiltration. International Dairy Journal, 12(9), 773-783. http://dx.doi.org/10.1016/S0958-6946(02)00070-5

Pestana, M. H., \& Gageiro, J. N. (2014). Análise de Dados para Ciências Sociais - A complementaridade do SPSS (6. ed.). Lisboa: Edições Sílabo.

Rohm, A. J., \& Swaminathan, V. (2004). A typology of online shoppers based on shopping motivations. Journal of Business Research, 57(7), 748-757. http://dx.doi.org/10.1016/S0148-2963(02)00351-X

Stevens, J. P. (2009). Applied multivariate statistics for the social sciences (5th ed.). New York: Routledge.

Funding: FCT - Fundação para a Ciência e Tecnologia (Portugal), UIDB/00681/2020 and Polytechnic Institute of Viseu, PROJ/CI\&DETS/CGD/0007. 